\title{
CALORIMETRIC DETERMINATION OF THE ENTHALPIES OF FORMATION OF HYDROTALCITE-LIKE SOLIDS AND THEIR USE IN THE GEOCHEMICAL MODELING OF METALS IN NATURAL WATERS
}

\author{
Rama kumar Allada ${ }^{1, \dagger}$, Edward Peltier ${ }^{2}$, Alexandra Navrotsky $^{1}{ }^{*}$, William H. Casey ${ }^{3}$, \\ C. Annette Johnson ${ }^{4}$, Hillary Thompson Berbeco ${ }^{5}$ and Donald L. Sparks ${ }^{2}$ \\ ${ }^{1}$ Thermochemistry Facility and NEAT ORU, Department of Chemical Engineering and Materials Science, University of \\ California, Davis, CA 95616, USA \\ ${ }^{2}$ Department of Plant and Soil Sciences, University of Delaware, Newark, DE 19716, USA \\ ${ }^{3}$ Department of Chemistry, University of California, Davis, CA 95616, USA \\ ${ }^{4}$ Swiss Federal Institute of Environmental Science and Technology (EAWAG), Postfach 611, CH-6800 Dübendorf, Switzerland \\ ${ }^{5}$ Franklin W. Olin College of Engineering, Needham, MA 02492, USA
}

\begin{abstract}
Interest in hydrotalcite-like compounds has grown due to their role in controlling the mobility of aqueous metals in the environment as well as their use as catalysts, catalyst precursors and specialty chemicals. Although these materials have been studied in a number of contexts, little is known of their thermodynamic properties. High-temperature oxide melt solution calorimetry was used to measure the standard enthalpy of formation for compounds $M(\mathrm{II})_{1-x} \mathrm{Al}_{x}(\mathrm{OH})_{2}\left(\mathrm{CO}_{3}\right)_{x / 2} \cdot m \mathrm{H}_{2} \mathrm{O}(0.2<x<0.4, M$ (II) $=$ $\mathrm{Mg}, \mathrm{Co}, \mathrm{Ni}$ and $\mathrm{Zn})$. The enthalpy of formation of these compounds from the relevant single cation phases was also determined. The formation of HTLCs results in a $5-20 \mathrm{~kJ} / \mathrm{mol}$ enthalpy stabilization from the single cation hydroxides and carbonates and water. The data are correlated to two variables: the ratio of divalent to trivalent cation in the solid $(M(\mathrm{II}) / \mathrm{Al})$ and the identity of the divalent cation. It was observed that the $M(\mathrm{II}) / \mathrm{Al}$ ratio exerts a minor influence on the enthalpy of formation from single-cation phases, while greater differences in stabilization resulted from changes in the chemical nature of the divalent cation. However, the data do not support any statistically significant correlation between the composition of HTLCs and their heats of formation. Equilibrium geochemical calculations based upon the thermodynamic data illustrate the effect of HTLCs on the speciation of metals in natural waters. These calculations show that, in many cases, HTLCs form even in waters that are undersaturated with respect to the individual divalent metal hydroxides and carbonates. Phase diagrams and stability diagrams involving Ni-bearing HTLCs and the single-cation components are presented. The Ni(II) concentration as a function of $\mathrm{pH}$ as well as the stability diagram for the equilibrium among minerals in the $\mathrm{CaO}-\mathrm{NiO}-\mathrm{Al}_{2} \mathrm{O}_{3}-\mathrm{SiO}_{2}-$ $\mathrm{CO}_{2}-\mathrm{H}_{2} \mathrm{O}$ system at $298 \mathrm{~K}$ are plotted.
\end{abstract}

Key Words-Aqueous Solubilities, Calorimetry, Enthalpy of Formation, Hydrotalcite-like Solids.

\section{INTRODUCTION}

Interest in hydrotalcite-like compounds (HTLCs) has grown due to their role in controlling the mobility of aqueous metals in the environment as well as their use as catalysts, catalyst precursors and specialty chemicals (Cavani and Trifirò, 1991; Bellotto et al., 1996; Scheidegger et al., 1997; Towle et al., 1997). Even though numerous applications have been developed for HTLCs, and a great deal of research has centered on their effects on total dissolved concentrations of transition metals in the environment, little is known about their energetics. Thermodynamic data are essential for the development of novel chemical processes and new materials, as well as for more accurate calculations in environmental chemistry. Hydrotalcites have the general stoichiometry $M(\mathrm{II})_{1-x} M(\mathrm{III})_{x}(\mathrm{OH})_{2}\left(A^{n-}\right)_{x / n} \cdot m \mathrm{H}_{2} \mathrm{O}$ and

\footnotetext{
* E-mail address of corresponding author:

anavrotsky@ucdavis.edu

†Present address: Mail Code ES4, NASA Johnson Space Center, Houston, TX 77058, USA

DOI: $10.1346 /$ CCMN.2006.0540401
}

are composed of brucite-type hydroxide sheets intercalated with anions $\left[A^{n-}\right]$. The variable $x$ represents the fraction of cations based on one mole and $m$ represents the moles of water in the sample. Hydrotalcites exhibit a wide variety of structural and compositional variations. They contain a number of cations including Mn(II), $\mathrm{Mg}(\mathrm{II}), \mathrm{Co}(\mathrm{II}), \mathrm{Ni}(\mathrm{II}), \mathrm{Zn}(\mathrm{II}), \mathrm{Fe}(\mathrm{II}), \mathrm{Al}(\mathrm{III}), \mathrm{Fe}(\mathrm{III})$ and $\mathrm{Cr}(\mathrm{III})$. Interlayer anions such as $\mathrm{CO}_{3}^{2-}, \mathrm{NO}_{3}^{-}, \mathrm{Cl}^{-}, \mathrm{SO}_{4}^{2-}$ have been reported (Cavani and Trifirò, 1991; Bellotto et al., 1996; Scheidegger et al., 1997; Towle et al., 1997; Thompson et al., 1999a).

In an initial study (Allada et al., 2002), the thermodynamic properties of hydrotalcite-like compounds were estimated by considering them as thermodynamically similar to mechanical mixtures of hydroxides and carbonates and water. Experimental results for the enthalpy of formation of some Co-Al hydroxycarbonates demonstrated that the enthalpy difference between the mechanical mixture of $\beta-\mathrm{Co}(\mathrm{OH})_{2}$, $\mathrm{CoCO}_{3}, \mathrm{Al}(\mathrm{OH})_{3}$ (gibbsite) and water, and the hydrotalcite-like phases was small $(<10 \mathrm{~kJ} / \mathrm{mol}$ and within experimental error in some cases). Because of the 
structural similarity between the single-cation components and the hydrotalcites, it was assumed that the entropy difference would be small as well. Measurements of the third-law entropy of the HTLC, $\mathrm{Mg}_{0.74} \mathrm{Al}_{0.26}(\mathrm{OH})_{2}\left(\mathrm{CO}_{3}\right)_{0.13} \cdot 0.39 \mathrm{H}_{2} \mathrm{O}$, show that at room temperature, the contribution of entropy towards the total free energy $(\mathrm{T} \Delta \mathrm{S})$ is on the order of a $2-3 \mathrm{~kJ} / \mathrm{mol}$ reduction (Allada et al., 2005). Comparisons of the heats of formation for several compounds along the $\mathrm{Mg}_{1-x} \mathrm{Al}_{x}(\mathrm{OH})_{2}\left(\mathrm{CO}_{3}\right)_{x / 2} \cdot m \mathrm{H}_{2} \mathrm{O}$ join show small differences in the heats of formation as a function of aluminum content. These results suggest that these differences are not substantial enough to promote significant thermodynamic preferences for any given $\mathrm{Mg} / \mathrm{Al}$ ratio (Allada et al., 2005). It is more likely that solution conditions, namely the relative activities of the cations in solution and the $\mathrm{pH}$, control the composition of the hydrotalcite phase. Thus hydrotalcites form over a range of compositions in a variety of conditions (Pausch et al., 1986; Reichle, 1986a; Thevenot et al., 1989).

The goal of this study was to delve further into the systematics of these phases and expand the database of calorimetric data, as well as use these data in equilibrium modeling applicable to real environmental systems. The experimental work explores the effect upon the enthalpy of formation of two compositional parameters: (1) the ratio of divalent to trivalent cations (M(II)/Al); and (2) the identity of the divalent cation. Pure carbonate systems were considered because of their relative abundance in natural systems. The MINTEQ geochemical assessment model (Allison et al., 1991; Gustafsson, 2003) was then used to contrast the speciation of divalent metals in natural water when HTLCs were included vs. the cases in which the endmember hydroxides and carbonates were considered. The solubility products of several HTLCs were calcu- lated by combining the data for the heat of formation with an estimate for the entropy contribution based on earlier work on the $\mathrm{MgO}-\mathrm{Al}_{2} \mathrm{O}_{3}-\mathrm{CO}_{2}-\mathrm{H}_{2} \mathrm{O}$ system (Allada et al., 2005).

\section{EXPERIMENTAL METHODS}

\section{Synthesis and characterization}

The sources of the hydrotalcites and the reference materials used in this study are listed in Table 1. Hydrotalcite-like compounds bearing $\mathrm{Co}$ and $\mathrm{Mg}$ were synthesized at the Thermochemistry Facility, University of California at Davis, by a coprecipitation method (Reichle, 1986a, 1986b). Nitrate salts of various cations $(M(\mathrm{II})=\mathrm{Co}$ or $\mathrm{Mg}$ ) were used to synthesize samples bearing different divalent cations with $\mathrm{Al}(\mathrm{III})$. The proportion of $M(\mathrm{II})\left(\mathrm{NO}_{3}\right)_{2} \cdot 6 \mathrm{H}_{2} \mathrm{O}$ and $\mathrm{Al}\left(\mathrm{NO}_{3}\right)_{3} \cdot 9 \mathrm{H}_{2} \mathrm{O}$ in the metal nitrate reagent solution was adjusted to synthesize HTLCs of varying M(II)/Al ratio. The metal nitrate solution was added to a solution of $0.033 \mathrm{M}$ $\mathrm{Na}_{2} \mathrm{CO}_{3}$, and the $\mathrm{pH}$ (measured by $\mathrm{pH}$ meter) was maintained at $9.0 \pm 0.3$ by the periodic dropwise addition of $2.0 \mathrm{~N} \mathrm{NaOH}$ solution. The addition of the metal nitrate to $\mathrm{Na}_{2} \mathrm{CO}_{3}$ was done slowly to produce a crystalline product in small $(<300 \mathrm{mg})$ batches. The Zn-bearing sample was synthesized at the Swiss Federal Institute of Environmental Science and Technology using co-precipitation at low supersaturation (Johnson and Glasser, 2003).

Powder X-ray diffraction (XRD) on a Scintag PAD-V diffractometer using $\mathrm{CuK} \alpha$ radiation at $45 \mathrm{kV}$ and $40 \mathrm{~mA}$ was used to confirm homogeneity and bulkphase crystallinity of all samples synthesized at the Thermochemistry Facility. Although the peaks in XRD patterns exhibited minor broadening due to small particle size $(<100 \mathrm{~nm})$, they were still sharp and well

Table 1. History of HTLCs used in this study.

\begin{tabular}{|c|c|}
\hline Sample & Synthesis history \\
\hline $\mathrm{Co}_{0.68} \mathrm{Al}_{0.32}(\mathrm{OH})_{2}\left(\mathrm{CO}_{3}\right)_{0.16} \cdot 0.78 \mathrm{H}_{2} \mathrm{O}$ & H. Thompson Berbeco at Los Alamos National Laboratory \\
\hline $\mathrm{Co}_{0.69} \mathrm{Al}_{0.31}(\mathrm{OH})_{2}\left(\mathrm{CO}_{3}\right)_{0.16} \cdot 0.67 \mathrm{H}_{2} \mathrm{O}$ & Synthesized \\
\hline $\mathrm{Co}_{0.70} \mathrm{Al}_{0.30}(\mathrm{OH})_{2}\left(\mathrm{CO}_{3}\right)_{0.16} \cdot 0.23 \mathrm{H}_{2} \mathrm{O}$ & Annette Johnson at EAWAG (Johnson and Glasser, 2003) \\
\hline $\mathrm{Co}_{0 \cdot 76} \mathrm{Al}_{0.24}(\mathrm{OH})_{2}\left(\mathrm{CO}_{3}\right)_{0.12} \cdot 0.81 \mathrm{H}_{2} \mathrm{O}$ & H. Thompson Berbeco at Los Alamos National Laboratory \\
\hline $\mathrm{Co}_{0.80} \mathrm{Al}_{0.20}(\mathrm{OH})_{2}\left(\mathrm{CO}_{3}\right)_{0.10} \cdot 0.75 \mathrm{H}_{2} \mathrm{O}$ & Synthesized \\
\hline $\mathrm{Co}_{0.83} \mathrm{Al}_{0.17}(\mathrm{OH})_{2}\left(\mathrm{CO}_{3}\right)_{0.09} \cdot 0.29 \mathrm{H}_{2} \mathrm{O}$ & Synthesized \\
\hline $\mathrm{Mg}_{0.67} \mathrm{Al}_{0.33}(\mathrm{OH})_{2}\left(\mathrm{CO}_{3}\right)_{0.16} \cdot 0.70 \mathrm{H}_{2} \mathrm{O}$ & Synthesized \\
\hline $\mathrm{Mg}_{0.66} \mathrm{Al}_{0.34}(\mathrm{OH})_{2}\left(\mathrm{CO}_{3}\right)_{0.17} \cdot 0.69 \mathrm{H}_{2} \mathrm{O}$ & Synthesized \\
\hline $\mathrm{Mg}_{0.69} \mathrm{Al}_{0.31}(\mathrm{OH})_{2}\left(\mathrm{CO}_{3}\right)_{0.16} \cdot 0.30 \mathrm{H}_{2} \mathrm{O}$ & Annette Johnson at EAWAG (Johnson and Glasser, 2003) \\
\hline $\mathrm{Mg}_{0.74} \mathrm{Al}_{0.26}(\mathrm{OH})_{2}\left(\mathrm{CO}_{3}\right)_{0.13} \cdot 0.39 \mathrm{H}_{2} \mathrm{O}$ & (Allada et al., 2005) \\
\hline $\mathrm{Mg}_{0.73} \mathrm{Al}_{0.27}(\mathrm{OH})_{2}\left(\mathrm{CO}_{3}\right)_{0.17} \cdot 0.83 \mathrm{H}_{2} \mathrm{O}$ & J.D. Pless (Sandia National Laboratories) \\
\hline $\mathrm{Ni}_{0.69} \mathrm{Al}_{0.31}(\mathrm{OH})_{2}\left(\mathrm{CO}_{3}\right)_{0.16} \cdot 0.37 \mathrm{H}_{2} \mathrm{O}$ & Annette Johnson at EAWAG (Johnson and Glasser, 2003) \\
\hline $\mathrm{Ni}_{0.66} \mathrm{Al}_{0.34}(\mathrm{OH})_{2}\left(\mathrm{CO}_{3}\right)_{0.17} \cdot 0.42 \mathrm{H}_{2} \mathrm{O}$ & E. Peltier (University of Delaware) \\
\hline $\mathrm{Ni}_{0.77} \mathrm{Al}_{0.23}(\mathrm{OH})_{2}\left(\mathrm{CO}_{3}\right)_{0.12} \cdot 0.33 \mathrm{H}_{2} \mathrm{O}$ & Synthesized \\
\hline $\mathrm{Ni}_{0.67} \mathrm{Al}_{0.33}(\mathrm{OH})_{2}\left(\mathrm{CO}_{3}\right)_{0.17} \cdot 0.41 \mathrm{H}_{2} \mathrm{O}$ & E. Peltier (University of Delaware) \\
\hline $\mathrm{Ni}_{0.64} \mathrm{Al}_{0.36}(\mathrm{OH})_{2}\left(\mathrm{CO}_{3}\right)_{0.18} \cdot 0.46 \mathrm{H}_{2} \mathrm{O}$ & E. Peltier (University of Delaware) \\
\hline $\mathrm{Zn}_{0.67} \mathrm{Al}_{0.33}(\mathrm{OH})_{2}\left(\mathrm{CO}_{3}\right)_{0.17} \cdot 0.30 \mathrm{H}_{2} \mathrm{O}$ & Annette Johnson at EAWAG (Johnson and Glasser, 2003) \\
\hline
\end{tabular}


defined. No broad features, characteristic of X-ray amorphous phases, were observed. Although XRD cannot confirm full crystallinity of our samples on the nanoscale, it can be argued that these fine-grained samples are characteristic of the phases formed in natural environments, and thus the thermochemical measurements in this study are relevant to the lowtemperature geochemistry setting in which HTLCs occur. To confirm that no anions other than carbonate were present, Fourier transform infrared (FTIR) spectra were collected using the $\mathrm{KBr}$ pellet method on a Bruker Equinox 55 spectrometer in transmission mode. The cation ratio $(M(\mathrm{II}) / \mathrm{Al})$ was determined by inductively coupled plasma-optical emission spectroscopy (Galbraith Laboratories) or by electron microprobe analysis (EMPA) on a Cameca SX-50 electron microprobe. Elemental analysis (ASTM D5291, Galbraith Laboratories) was used to determine the carbon content of the HTLCs. The water content was determined by Karl Fisher titration (Galbraith Laboratories) and confirmed with thermogravimetric analysis using a Netzsch 449C STA system. Samples of anhydrous oxides and the end-member carbonates and hydroxides were synthesized at the Thermochemistry Facility, University of California at Davis, or purchased.

Ni-bearing hydrotalcite-like phases were prepared at the University of Delaware. Solutions of Ni and Al were prepared from the respective nitrate salts and then mixed together under acidic conditions $(\mathrm{pH} 3.2-3.8)$. The solutions were then titrated with a basic solution composed of $0.3 \mathrm{M} \mathrm{Na}_{2} \mathrm{CO}_{3}$ and $0.6 \mathrm{M} \mathrm{NaOH}$ to $\mathrm{pH}$ 6.9 and held at this $\mathrm{pH}$ for up to $6 \mathrm{~h}$, until base addition rates dropped below $2 \mathrm{~mL} / \mathrm{h}$. Precipitates were prepared using solution ratios of $\mathrm{Ni}$ to $\mathrm{Al}$ of $10: 1,5: 1$, and $2: 1$.

The Ni-bearing HTLCs were characterized using XRD, and X-ray absorption spectroscopy (XAS). The XAS spectra at the $\mathrm{NiK} \alpha$ edge were collected in transmission mode at beamline X-11A of the National Synchrotron Light Source at Brookhaven National Laboratory using a $\mathrm{Si}(111)$ monochromator detuned by $25 \%$ to reduce higher-order harmonic interference. Ion chambers filled with $\mathrm{N}_{2}$ and a $\mathrm{He} / \mathrm{Ar}$ mixture were used to record incident and transmitted intensity, respectively. The NiK edge was calibrated using a reference Ni foil. Because these HTLCs were formed in conditions similar to those found in natural waters (rapid crystallization in near-neutral $\mathrm{pH}$ ), it was expected they could be poorly crystalline and possibly heterogeneous at the nanoscale. Although the XAS cannot confirm that these phases are uniformly crystalline at the nanoscale, the results support that these phases are uniformly hydrotalcitelike in terms of local coordination.

The Ni:Al ratios in the solids were determined by flame atomic absorption spectroscopy after hot plate digestion in concentrated nitric acid. The anion content was determined by FTIR using the drift technique and the molar concentration of carbonate and nitrate in these
HTLCs was determined by total $\mathrm{C}$ and $\mathrm{N}$ analysis. Both analyses confirmed that only carbonate was present in the interlayer of the Ni-bearing HTLCs. The water content of the samples was determined by mass loss on heating using high-resolution thermogravimetric analysis (TGA) performed on a TA Instruments 2950. Samples were heated from 303 to $1073 \mathrm{~K}$ under a $\mathrm{N}_{2}$ atmosphere with a maximum heating rate of $20 \mathrm{~K} / \mathrm{min}$, with water loss occurring by $408 \mathrm{~K}$.

\section{High-temperature oxide melt solution calorimetry}

The enthalpy of drop solution in lead borate $\left(2 \mathrm{PbO} \cdot \mathrm{B}_{2} \mathrm{O}_{3}\right)$ at $973 \mathrm{~K}$ was measured in a custom-built twin Tian-Calvet solution calorimeter (Navrotsky, 1997). Pelletized samples of approximately 5 or $15 \mathrm{mg}$ were dropped from room temperature into a platinum crucible containing $2 \mathrm{PbO} \cdot \mathrm{B}_{2} \mathrm{O}_{3}$ at $973 \mathrm{~K}$. A flowing argon atmosphere $(60-90 \mathrm{~mL} / \mathrm{min})$ was maintained within the calorimeter to drive off $\mathrm{H}_{2} \mathrm{O}$ and $\mathrm{CO}_{2}$ that evolved during the dissolution of water and carbonatebearing phases (Navrotsky et al., 1994). The calorimeter was calibrated by measuring the heat content of 5 and $15 \mathrm{mg}$ pellets of corundum.

\section{Speciation calculations}

MINTEQ is a geochemical speciation code used for predicting and modeling the behavior of species in dilute aqueous systems (Allison et al., 1991; Gustafsson, 2003). Given a set of data for the chemistry of a sample of water and thermodynamic data, the software performs mass and charge balance calculations to predict the equilibrium speciation and concentrations of aqueous species. The calculations demonstrate the equilibrium speciation of aqueous divalent metals in a natural water when a hydrotalcite-like phase $\left(M(\mathrm{II})_{1-x} \mathrm{Al}_{x}(\mathrm{OH})_{2}\left(\mathrm{CO}_{3}\right)_{x / 2} \cdot m \mathrm{H}_{2} \mathrm{O}\right.$, $M(\mathrm{II})=\mathrm{Co}, \mathrm{Ni}, \mathrm{Mg}, \mathrm{Zn})$ is allowed to precipitate. The equilibrium constant for dissolution, or solubility product $\left(\mathrm{K}_{\mathrm{sp}}\right)$ of the HTLC was calculated according to the following chemical reaction

$$
\begin{gathered}
M(\mathrm{II})_{1-x} \mathrm{Al}_{x}(\mathrm{OH})_{2}\left(\mathrm{CO}_{3}\right)_{x / 2} \cdot m \mathrm{H}_{2} \mathrm{O}+2 \mathrm{H}^{+}(\mathrm{aq}) \rightarrow \\
(1-x) M^{2+}(\mathrm{aq})+x \mathrm{Al}^{3+}(\mathrm{aq})+ \\
x / 2 \mathrm{CO}_{3}^{2-}(\mathrm{aq})+(2+m) \mathrm{H}_{2} \mathrm{O}
\end{gathered}
$$

The solubility product is calculated from the free energy of this reaction $\left(\Delta G_{\mathrm{rxn}}\right)$ by

$$
\Delta G=-\mathrm{R} T \ln \mathrm{K}
$$

where $T=298.15 \mathrm{~K}$ and $\mathrm{R}$ is the gas constant $(8.314 \mathrm{~J} /$ mol K). Table 2 lists the free energies of formation that were used to calculate the free energies of reactions for the solubility products. The calculations examine the stability of the HTLCs in a simple model aqueous environment given three controlling conditions: (1) $\mathrm{Al}^{3+}(\mathrm{aq})$ activity controlled by gibbsite and $\mathrm{CO}_{2}$ partial pressure at atmospheric levels $\left(10^{-3.5} \mathrm{~atm}\right)$; (2) $\mathrm{Al}^{3+}(\mathrm{aq})$ activity controlled by kaolinite and $\mathrm{CO}_{2}$ partial pressure at atmospheric levels $\left(10^{-3.5} \mathrm{~atm}\right)$; and 
Table 2. Free energies of formation for species used in equilibrium calculations.

\begin{tabular}{ll}
\hline Species & \multicolumn{1}{c}{$\Delta G_{\mathrm{f}}^{0}(\mathrm{~kJ} / \mathrm{mol})$} \\
\hline $\mathrm{H}^{+}$ & 0.0 (Robie and Hemingway, 1995) \\
$\mathrm{Mg}^{2+}$ & -456.0 (Rossini et al., 1952) \\
$\mathrm{Co}^{2+}$ & -54.4 (Robie and Hemingway, 1995) \\
$\mathrm{Ni}^{2+}$ & -45.6 (Robie and Hemingway, 1995) \\
$\mathrm{Zn}^{2+}$ & -147.3 (Robie and Hemingway, 1995) \\
$\mathrm{Al}^{3+}$ & 481.2 (Rossini et al., 1952) \\
$\mathrm{CO}_{3}^{2-}$ & -528.1 (Wagman et al., 1982) \\
$\mathrm{H}_{2} \mathrm{O}$ (1) & -237.2 (Robie and Hemingway, 1995) \\
\hline
\end{tabular}

(3) $\mathrm{Al}^{3+}$ (aq) activity controlled by kaolinite and $\mathrm{CO}_{3}^{2-}(\mathrm{aq})$ controlled by calcite.

The speciation of all components was calculated at the fixed $\mathrm{pH}$ of 7 . The composition of the model aqueous solution used in the calculations is presented in Table 3. The initial concentrations of aqueous species for these calculations are presented in the second column of Table 3. To determine the level of saturation of a phase, one calculates the saturation index (SI), which is essentially the ratio of the activities of relevant species (IAP) and the equilibrium constant

$$
\mathrm{SI}=\log \left(\frac{\mathrm{IAP}}{\mathrm{K}}\right)
$$

A positive SI indicates supersaturation with respect to a phase, while a negative SI indicates undersaturation. A SI of zero indicates that the phase is at equilibrium with its aqueous components. The activities are calculated as the product of the activity coefficient of a given species $\left(\gamma_{i}\right)$ and its concentration in solution. The software uses the Davies Equation to calculate activity coefficients.
Table 3. Composition of model water.

\begin{tabular}{lc}
\hline Species & $\begin{array}{c}\text { Concentration } \\
(\mathrm{mol} / \mathrm{L})\end{array}$ \\
\hline $\mathrm{Ni}^{2+}$ & $1.00 \mathrm{E}-06$ \\
$\mathrm{Zn}^{2+}$ & $1.00 \mathrm{E}-06$ \\
$\mathrm{Mg}^{2+}$ & $2.12 \mathrm{E}-06$ \\
$\mathrm{Co}^{2+}$ & $1.00 \mathrm{E}-06$ \\
$\mathrm{Ca}^{2+}$ & $4.70 \mathrm{E}-05$ \\
$\mathrm{Na}^{+}$ & $9.70 \mathrm{E}-06$ \\
$\mathrm{~K}^{+}$ & $6.60 \mathrm{E}-07$ \\
$\mathrm{SO}_{4}^{2-}$ & $2.00 \mathrm{E}-06$ \\
$\mathrm{Cl}^{-}$ & $1.02 \mathrm{E}-04$ \\
$\mathrm{NO}_{3}^{-}$ & $8.60 \mathrm{E}-06$ \\
$\mathrm{pH}^{2-}$ & 7.0 \\
$\mathrm{pCO}_{2}$ & 3.5
\end{tabular}

\section{RESULTS}

\section{High-temperature oxide melt solution calorimetry}

The enthalpy data for the relevant anhydrous oxides and the single-cation compounds are listed in Table 4. The enthalpy of drop solution $\left(\Delta H_{\mathrm{dsol}}\right)$ indicates the heat effect associated with dropping the sample from room temperature into solvent in the calorimeter and includes contributions from the dissolution of the sample in the solvent at calorimeter temperature (with evolution of $\mathrm{CO}_{2}$ and $\mathrm{H}_{2} \mathrm{O}$ ), and the effects due to heat pickup and any phase transitions on heating the sample to calorimeter temperature. For each sample, the reported enthalpy of drop solution represents the mean of several drop solution measurements (usually 5-10) with an associated error of two standard deviations from the mean. The numbers in parentheses give the number of

Table 4. Enthalpies of drop solution at $975 \mathrm{~K}$ in $2 \mathrm{PbO} \cdot \mathrm{B}_{2} \mathrm{O}_{3}$ and derived standard formation enthalpies.

\begin{tabular}{|c|c|c|c|}
\hline Sample & $\Delta H_{\mathrm{dsol}}(\mathrm{kJ} / \mathrm{mol})$ & $\Delta_{\mathrm{f}} H^{\mathrm{ox}}(\mathrm{kJ} / \mathrm{mol})$ & $\Delta H_{\mathrm{f}}^{0}(\mathrm{~kJ} / \mathrm{mol})$ \\
\hline $\mathrm{MgO}$ & $\begin{array}{l}37.93 \pm 2.11 \text { (Chai and } \\
\text { Navrotsky, 1996) }\end{array}$ & - & $-601.49 \pm 0.49$ (Robie and Hemingway, 1995) \\
\hline $\mathrm{CoO}$ & $57.23 \pm 0.84(9)^{*}$ & - & $-237.94 \pm 1.255$ (Robie and Hemingway, 1995) \\
\hline $\mathrm{NiO}$ & $\begin{array}{l}78.341 \pm 0.81 \text { (Wang and } \\
\text { Navrotsky, 2004) }\end{array}$ & - & $-239.7 \pm 0.418$ (Robie and Hemingway, 1995) \\
\hline $\mathrm{ZnO}$ & $51.98 \pm 0.88(6)$ & - & $-350.46 \pm 0.27$ (Robie and Hemingway, 1995) \\
\hline$\alpha-\mathrm{Al}_{2} \mathrm{O}_{3}$ & $108.62 \pm 0.99(7)$ & - & $-1675.7 \pm 1.3$ (Robie and Hemingway, 1995) \\
\hline $\mathrm{CO}_{2}$ & 32.07 & - & $-393.51 \pm 0.13$ (Robie and Hemingway, 1995) \\
\hline $\mathrm{H}_{2} \mathrm{O}$ & 69.0 & - & $-285.83 \pm 0.042$ (Robie and Hemingway, 1995) \\
\hline $\mathrm{Al}(\mathrm{OH})_{3}$ (Gibbsite) & $184.56+0.97(9)$ & $-26.75 \pm 1.08$ & $-1293.34 \pm 1.30$ \\
\hline$\beta-\mathrm{Co}(\mathrm{OH})_{2}$ & $147.16 \pm 1.8(6)$ & $-20.93 \pm 1.98$ & $-544.70 \pm 2.35$ \\
\hline $\mathrm{Mg}(\mathrm{OH})_{2}$ & $144.35 \pm 1.04(8)$ & $-37.42 \pm 2.35$ & $-924.74 \pm 2.40$ \\
\hline$\beta-\mathrm{Ni}(\mathrm{OH})_{2}$ & $162.15 \pm 1.30(5)$ & $-14.81 \pm 1.30$ & $-540.34 \pm 1.37$ \\
\hline $\mathrm{Zn}(\mathrm{OH})_{2}$ & - & - & -642 (Woods and Garrels, 1987) \\
\hline $\mathrm{MgCO}_{3}$ & $186.7 \pm 1.44(7)$ & $-116.7 \pm 2.55$ & $-1111.7 \pm 2.55$ \\
\hline $\mathrm{NiCO}_{3}$ & - & - & -689.1 (Woods and Garrels, 1987) \\
\hline $\mathrm{ZnCO}_{3}$ & - & - & $-812.78 \pm 2.93$ (Robie and Hemingway, 1995) \\
\hline $\mathrm{CoCO}_{3}$ & $203.66 \pm 0.73(7)$ & $-114.36 \pm 1.10$ & $-745.82 \pm 1.68$ \\
\hline
\end{tabular}

* The numbers in parentheses are the number of drop solution measurements taken for each sample. 
Table 5. Heat of formation of $M(\mathrm{II})_{1-x} \mathrm{Al}_{x}(\mathrm{OH})_{2}\left(\mathrm{CO}_{3}\right)_{x / 2} \cdot m \mathrm{H}_{2} \mathrm{O}$ from the oxides.

\begin{tabular}{ll}
\hline Step & \multicolumn{1}{c}{ Reaction } \\
\hline 1 & $M(\mathrm{II})_{1-x} \mathrm{Al}_{x}(\mathrm{OH})_{2}\left(\mathrm{CO}_{3}\right)_{x / 2} \cdot m \mathrm{H}_{2} \mathrm{O}(\mathrm{s}, 298) \rightarrow(1-x) M(\mathrm{II}) \mathrm{O}\left(\right.$ soln, 975) $+x / 2 \mathrm{Al}_{2} \mathrm{O}_{3}($ soln, 975$)+x / 2 \mathrm{CO}_{2}(\mathrm{~g}, 975)+$ \\
& $(1+m) \mathrm{H}_{2} \mathrm{O}(\mathrm{g}, 975)$ \\
2 & $(1-x) M(\mathrm{II}) \mathrm{O}(\mathrm{s}, 298) \rightarrow(1-x) M(\mathrm{II}) \mathrm{O}($ soln, 975$)$ \\
3 & $x / 2 \mathrm{Al}_{2} \mathrm{O}_{3}(\mathrm{~s}, 298) \rightarrow x / 2 \mathrm{Al}_{2} \mathrm{O}_{3}($ soln, 975) \\
4 & $(1+m) \mathrm{H}_{2} \mathrm{O}(1,298) \rightarrow(1+m) \mathrm{H}_{2} \mathrm{O}(\mathrm{g}, 975)$ \\
5 & $x / 2 \mathrm{CO}_{2}(\mathrm{~g}, 298) \rightarrow x / 2 \mathrm{CO}_{2}(\mathrm{~g}, 975)$ \\
$\mathrm{f}, \mathrm{ox}$ & $(1-x) M(\mathrm{II}) \mathrm{O}(\mathrm{s}, 298)+x / 2 \mathrm{Al}_{2} \mathrm{O}_{3}(\mathrm{~s}, 298)+x / 2 \mathrm{CO}_{2}(\mathrm{~g}, 298)+(1+m) \mathrm{H}_{2} \mathrm{O}(1,298) \rightarrow M(\mathrm{II})_{1-x} \mathrm{Al}_{x}(\mathrm{OH})_{2}(\mathrm{CO})_{x / 2}$ \\
& $\cdot m \mathrm{H}_{2} \mathrm{O}(\mathrm{s}, 298)$
\end{tabular}

$\Delta_{\mathrm{f}} H^{\mathrm{ox}}=-\Delta H_{1}+\Delta H_{2}+\Delta H_{3}+\Delta H_{4}+\Delta H_{5}$

drop solution measurements taken for each sample. Standard state enthalpies of formation $\left(\Delta H_{\mathrm{f}}^{0}\right)$ for compounds were determined by first calculating the enthalpies of formation from the oxides $\left(\Delta_{\mathrm{f}} H^{\mathrm{ox}}\right)$. Literature data for the standard enthalpies of formation for these oxides were used to calculate the enthalpies of formation from the elements for the HTLCs. Relatively large errors associated with the enthalpy of formation are due to the propagation of errors (Taylor, 1982) associated with the heats of formation of the reference phases that were used in the calculations.

Table 5 illustrates the thermochemical cycle used to calculate $\Delta_{\mathrm{f}} H^{\mathrm{ox}}$. The thermochemical cycle lists specific chemical reactions, the heat of reaction step, and the chemical state of various species. For example: $(\mathrm{s}, 298)=$ solid at $298 \mathrm{~K},(\mathrm{~g}, 975)=$ gas at $975 \mathrm{~K},($ soln, 975) $=$ solution at $975 \mathrm{~K}$. Table 6 presents the thermodynamic data for the HTLCs in this study. Table 7 lists the mineral phases that were used as the single cation compounds used for calculating $\Delta H^{\mathrm{scc}}$.

\section{Speciation calculations}

The calculated solubility products for the HTLCs are listed in Table 8 . The saturation indices of the HTLCs calculated from MINTEQ are listed in Table 9. The saturation indices provided for the three cases correspond to three controlling conditions: (1) $\mathrm{Al}^{3+}$ (aq) activity controlled by gibbsite and $\mathrm{CO}_{2}$ partial pressure at atmospheric levels $\left(10^{-3.5}\right.$ atm); (2) $\mathrm{Al}^{3+}$ (aq) activity controlled by kaolinite and $\mathrm{CO}_{2}$ partial pressure at atmospheric levels $\left(10^{-3.5}\right.$ atm); and (3) $\mathrm{Al}^{3+}(\mathrm{aq})$ activity controlled by kaolinite and $\mathrm{CO}_{3}^{2-}$ (aq) controlled by calcite. In all cases the dissolution of HTLC into aqueous species follows equation 1 .

\section{DISCUSSION}

\section{Systematics in the enthalpies of formation}

Thermodynamic measurements on a series of compounds in the $\mathrm{MgO}-\mathrm{Al}_{2} \mathrm{O}_{3}-\mathrm{CO}_{2}-\mathrm{H}_{2} \mathrm{O}$ showed minor variations in the enthalpy $\left(\Delta_{\mathrm{f}} H^{\mathrm{scc}}\right)$ with changes in

Table 6. Summary of heat of formation data for $M(\mathrm{II})_{1-x} \mathrm{Al}_{\mathrm{x}}(\mathrm{OH})_{2}\left(\mathrm{CO}_{3}\right)_{x / 2} \cdot m \mathrm{H}_{2} \mathrm{O}$ HTLCs.

\begin{tabular}{|c|c|c|c|c|}
\hline Sample & $\Delta H_{\mathrm{dsol}}(\mathrm{kJ} / \mathrm{mol})$ & $\Delta_{\mathrm{f}} H^{\mathrm{ox}}(\mathrm{kJ} / \mathrm{mol})$ & $\Delta H_{\mathrm{f}}^{0}(\mathrm{~kJ} / \mathrm{mol})$ & $\Delta_{\mathrm{f}} H^{\mathrm{scc}}(\mathrm{kJ} / \mathrm{mol})$ \\
\hline $\mathrm{Co}_{0.68} \mathrm{Al}_{0.32}(\mathrm{OH})_{2}\left(\mathrm{CO}_{3}\right)_{0.16} \cdot 0.78 \mathrm{H}_{2} \mathrm{O}$ & $226.98 \pm 1.24$ & $-42.80 \pm 1.50$ & $-1044.17 \pm 2.54$ & $-5.05 \pm 2.86$ \\
\hline $\mathrm{Co}_{0.69} \mathrm{Al}_{0.31}(\mathrm{OH})_{2}\left(\mathrm{CO}_{3}\right)_{0.16} \cdot 0.68 \mathrm{H}_{2} \mathrm{O}$ & $218.17 \pm 1.28$ & $-41.84 \pm 1.32$ & $-1006.26 \pm 1.62$ & $-4.42 \pm 2.15$ \\
\hline $\mathrm{Co}_{0.70} \mathrm{Al}_{0.30}(\mathrm{OH})_{2}\left(\mathrm{CO}_{3}\right)_{0.16} \cdot 0.23 \mathrm{H}_{2} \mathrm{O}$ & $212.18 \pm 1.08(6)$ & $-49.22 \pm 1.01$ & $-877.34 \pm 1.35$ & $-11.04 \pm 1.92$ \\
\hline $\mathrm{Co}_{0 \cdot 76} \mathrm{Al}_{0.24}(\mathrm{OH})_{2}\left(\mathrm{CO}_{3}\right)_{0.12} \cdot 0.81 \mathrm{H}_{2} \mathrm{O}$ & $228.50 \pm 1.25(4)$ & $-43.51 \pm 1.42$ & $-991.79 \pm 1.72$ & $-9.78 \pm 2.07$ \\
\hline $\mathrm{Co}_{0.80} \mathrm{Al}_{0.20}(\mathrm{OH})_{2}\left(\mathrm{CO}_{3}\right)_{0.10} \cdot 0.76 \mathrm{H}_{2} \mathrm{O}$ & $215.97 \pm 2.46$ & $-35.23 \pm 1.71$ & $-933.36 \pm 2.17$ & $-3.88 \pm 2.17$ \\
\hline $\mathrm{Co}_{0.83} \mathrm{Al}_{0.17}(\mathrm{OH})_{2}\left(\mathrm{CO}_{3}\right)_{0.09} \cdot 0.29 \mathrm{H}_{2} \mathrm{O}$ & $183.47 \pm 1.51$ & $-35.00 \pm 1.67$ & $-777.09 \pm 1.97$ & $-5.13 \pm 2.64$ \\
\hline $\mathrm{Mg}_{0.67} \mathrm{Al}_{0.33}(\mathrm{OH})_{2}\left(\mathrm{CO}_{3}\right)_{0.16} \cdot 0.70 \mathrm{H}_{2} \mathrm{O}$ & $222.67 \pm 1.26(5)$ & $-58.61 \pm 1.79$ & $-1284.65 \pm 1.75$ & $-11.01 \pm 1.56$ \\
\hline $\mathrm{Mg}_{0.66} \mathrm{Al}_{0.34}(\mathrm{OH})_{2}\left(\mathrm{CO}_{3}\right)_{0.17} \cdot 0.69 \mathrm{H}_{2} \mathrm{O}$ & $224.98 \pm 1.42(5)$ & $-57.99 \pm 1.68$ & $-1292.07 \pm 1.63$ & $-11.62 \pm 1.42$ \\
\hline $\mathrm{Mg}_{0.69} \mathrm{Al}_{0.31}(\mathrm{OH})_{2}\left(\mathrm{CO}_{3}\right)_{0.15} \cdot 0.30 \mathrm{H}_{2} \mathrm{O}$ & $200.69 \pm 0.85$ & $-62.68 \pm 1.66$ & $-1168.52 \pm 1.81$ & $-16.61 \pm 1.08$ \\
\hline $\mathrm{Mg}_{0.74} \mathrm{Al}_{0.26}(\mathrm{OH})_{2}\left(\mathrm{CO}_{3}\right)_{0.13} \cdot 0.39 \mathrm{H}_{2} \mathrm{O}$ & $197.50 \pm 1.18$ & $-55.43 \pm 1.43$ & $-1165.98 \pm 2.06$ & $-10.49 \pm 1.37$ \\
\hline $\mathrm{Mg}_{0.73} \mathrm{Al}_{0.27}(\mathrm{OH})_{2}\left(\mathrm{CO}_{3}\right)_{0.16} \cdot 0.83 \mathrm{H}_{2} \mathrm{O}$ & $226.11 \pm 1.06$ & $-54.42 \pm 1.87$ & $-1297.19 \pm 1.97$ & $-7.20 \pm 1.27$ \\
\hline $\mathrm{Ni}_{0.69} \mathrm{Al}_{0.31}(\mathrm{OH})_{2}\left(\mathrm{CO}_{3}\right)_{0.16} \cdot 0.37 \mathrm{H}_{2} \mathrm{O}$ & $211.10 \pm 1.01$ & $-40.71 \pm 1.16$ & $-918.42 \pm 1.21$ & $-15.83 \pm 1.28$ \\
\hline $\mathrm{Ni}_{0.66} \mathrm{Al}_{0.34}(\mathrm{OH})_{2}\left(\mathrm{CO}_{3}\right)_{0.17} \cdot 0.42 \mathrm{H}_{2} \mathrm{O}$ & $208.33 \pm 0.65$ & $-43.70 \pm 0.86$ & $-904.031 \pm 0.93$ & $-8.98 \pm 1.28$ \\
\hline $\mathrm{Ni}_{0.77} \mathrm{Al}_{0.23}(\mathrm{OH})_{2}\left(\mathrm{CO}_{3}\right)_{0.12} \cdot 0.33 \mathrm{H}_{2} \mathrm{O}$ & $202.84 \pm 1.03(5)$ & $-34.27 \pm 1.21$ & $-838.18 \pm 1.26$ & $-11.99 \pm 1.58$ \\
\hline $\mathrm{Ni}_{0.67} \mathrm{Al}_{0.33}(\mathrm{OH})_{2}\left(\mathrm{CO}_{3}\right)_{0.17} \cdot 0.41 \mathrm{H}_{2} \mathrm{O}$ & $217.89 \pm 1.95(5)$ & $-40.07 \pm 2.03$ & $-908.42 \pm 2.06$ & $-19.46 \pm 2.22$ \\
\hline $\mathrm{Ni}_{0.64} \mathrm{Al}_{0.36}(\mathrm{OH})_{2}\left(\mathrm{CO}_{3}\right)_{0.18} \cdot 0.46 \mathrm{H}_{2} \mathrm{O}$ & $220.33 \pm 1.38$ & $-33.09 \pm 1.48$ & $-942.41 \pm 1.53$ & $-17.72 \pm 1.72$ \\
\hline $\mathrm{Zn}_{0.67} \mathrm{Al}_{0.33}(\mathrm{OH})_{2}\left(\mathrm{CO}_{3}\right)_{0.17} \cdot 0.30 \mathrm{H}_{2} \mathrm{O}$ & $192.84 \pm 0.68$ & $-45.32 \pm 0.91$ & $-993.04 \pm 0.96$ & $-21.97 \pm 1.5$ \\
\hline
\end{tabular}


Table 7. Single-cation components used as reference phases for hydrotalcite formation.

\begin{tabular}{lccc}
\hline Mg-hydrotalcites & Co-hydrotalcites & Ni-hydrotalcites & Zn-hydrotalcites \\
\hline $\mathrm{Mg}(\mathrm{OH})_{2}-$ brucite & $\beta-\mathrm{Co}(\mathrm{OH})_{2}$ & $\beta-\mathrm{Ni}(\mathrm{OH})_{2}$ & $\varepsilon-\mathrm{Zn}(\mathrm{OH})_{2}$ \\
$\mathrm{Al}(\mathrm{OH})_{3}-$ gibbsite & $\mathrm{Al}(\mathrm{OH})_{3}-$ gibbsite & $\mathrm{Al}(\mathrm{OH})_{3}-$ gibbsite & $\mathrm{Al}(\mathrm{OH})_{3}-$ gibbsite \\
$\mathrm{MgCO}_{3}-$ magnesite & $\mathrm{CoCO}_{3}-$ spherocobaltite & $\mathrm{NiCO}_{3}-$ gaspeite & $\mathrm{ZnCO}_{3}-\mathrm{smithsonite}$ \\
$\mathrm{H}_{2} \mathrm{O}(\mathrm{l})$ & $\mathrm{H}_{2} \mathrm{O}(\mathrm{l})$ & $\mathrm{H}_{2} \mathrm{O}(\mathrm{l})$ & $\mathrm{H}_{2} \mathrm{O}(1)$ \\
\end{tabular}

composition (Allada et al., 2005). Therefore it was proposed that solution conditions, namely the relative cation activities and the $\mathrm{pH}$ were more important in controlling the composition of the hydrotalcite phase than differences in the thermodynamics among the solid phases. This trend is confirmed in the present work in that the data in Table 6 indicate only moderate differences in stabilization (as a function of $x$ ) for the $\mathrm{Co}, \mathrm{Mg}$ and $\mathrm{Ni}$ systems. Maximum variations are on the order of 5 to $12 \mathrm{~kJ} / \mathrm{mol}$.

However, there are somewhat larger differences in the thermodynamic stability of these phases as a function of the divalent cation. In general the $\mathrm{Zn}$-bearing phase is the most stable, followed by the $\mathrm{Ni}$-, $\mathrm{Mg}$ - and Co-bearing phases. The magnitudes of these enthalpies (ranging from 5 to $20 \mathrm{~kJ} / \mathrm{mol}$ ) show that hydrotalcite-like phases are in several cases significantly more stable than the mechanical mixtures of single cation components.

It was first suspected that the magnitude of $\Delta_{\mathrm{f}} H^{\mathrm{scc}}$ would be related to the size mismatch between the divalent cation (Co, $\mathrm{Mg}, \mathrm{Ni}$ or $\mathrm{Zn}$ ) and $\mathrm{Al}(\mathrm{III})$. The substitution of $\mathrm{Al}$ (III) for $M(\mathrm{II})$ in the brucite-type sheet causes strains to the metal-oxygen bonds around the substitution site, which would destabilize the structure. A greater mismatch between the radii of the $M(\mathrm{II}) / \mathrm{Al}(\mathrm{III})$ cations would result in lower stability, thus reducing the magnitude of $\Delta_{\mathrm{f}} H^{\mathrm{scc}}$. If $\Delta_{\mathrm{f}} H^{\mathrm{scc}}$ scaled according to the size mismatch, then the Ni-bearing phases would be the most stable while the Zn-bearing phases would be the least stable. However, the results show the opposite in that the $\mathrm{Zn}-\mathrm{HTLC}$ is the most stable phase $\left(\Delta_{\mathrm{f}} H^{\mathrm{scc}}=\right.$ $-22.0 \mathrm{~kJ} / \mathrm{mol}$ ), while the Co-bearing HTLCs are the least stable, with $\mathrm{Ni}$ intermediate. The data therefore do not support a simple correlation between the mismatch in size of the divalent cations and $\mathrm{Al}$ (III) and heat of formation from the single-cation components. At this point, no obvious crystal chemical rationalization can be made for the pattern of $\Delta_{\mathrm{f}} H^{\mathrm{scc}}$ that has been found.

Table 8. Solubility products for $M(\mathrm{II})_{1-x} \mathrm{Al}_{x}(\mathrm{OH})_{2}\left(\mathrm{CO}_{3}\right)_{x / 2}$ $\cdot m \mathrm{H}_{2} \mathrm{O}$.

\begin{tabular}{lc}
\hline Sample & Log K sp \\
\hline $\mathrm{Ni}_{0.69} \mathrm{Al}_{0.31}(\mathrm{OH})_{2}\left(\mathrm{CO}_{3}\right)_{0.16} \cdot 0.37 \mathrm{H}_{2} \mathrm{O}$ & 2.24 \\
$\mathrm{Co}_{0.76} \mathrm{Al}_{024}(\mathrm{OH})_{2}\left(\mathrm{CO}_{3}\right)_{0.12} \cdot 0.81 \mathrm{H}_{2} \mathrm{O}$ & 7.12 \\
$\mathrm{Zn}_{0.67} \mathrm{Al}_{0.33}(\mathrm{OH})_{2}\left(\mathrm{CO}_{3}\right)_{0.17} \cdot 0.30 \mathrm{H}_{2} \mathrm{O}$ & 3.73 \\
$\mathrm{Mg}_{0.74} \mathrm{Al}_{26}(\mathrm{OH})_{2}\left(\mathrm{CO}_{3}\right)_{0.13} \cdot 0.39 \mathrm{H}_{2} \mathrm{O}$ & 9.82 \\
\hline
\end{tabular}

Effects of HTLC formation on the speciation of aqueous metals

The solubility products for the $M(\mathrm{II})_{1-x} \mathrm{Al}_{x}(\mathrm{OH})_{2}\left(\mathrm{CO}_{3}\right)_{x / 2}$ $\cdot m \mathrm{H}_{2} \mathrm{O}$ (Co-HTLC, Mg-HTLC, Ni-HTLC and Zn-HTLC) predict decreases in solubility from the mechanical mixture ranging from one to four orders of magnitude. The values for the $\mathrm{Co}, \mathrm{Ni}$ and $\mathrm{Zn}$-bearing phases agree well with reported $\log \mathrm{K}_{\mathrm{sp}}$ values for hydrotalcites reported by Johnson (Johnson and Glasser, 2003) $\left(\log \mathrm{K}_{\mathrm{sp}} \approx 1.38\right)$, which are based on solubility measurements. The saturation indices in Table 9 show that in all three cases, the water is supersaturated with the $\mathrm{Zn}$ - and Ni-HTLCs while being undersaturated with respect to the hydroxides $\left(\beta-\mathrm{Ni}(\mathrm{OH})_{2}\right.$ and $\left.\varepsilon-\mathrm{Zn}(\mathrm{OH})_{2}\right)$. Magnesium forms a number of other mineral phases in natural waters so supersaturation of $\mathrm{Mg}$-hydrotalcite $\left(\mathrm{Mg}_{0.74} \mathrm{Al}_{0.26}\right.$ $\left.(\mathrm{OH})_{2}\left(\mathrm{CO}_{3}\right)_{0.13} \cdot 0.39 \mathrm{H}_{2} \mathrm{O}\right)$ is not generally expected.

The formation of HTLCs during the sorption of divalent metals onto Al-rich phases has been demonstrated by both spectroscopic studies and dissolution experiments (Scheidegger et al., 1998; Thompson et al., 1999 b) in waters that were undersaturated with respect to the $M(\mathrm{II})(\mathrm{OH})_{2}$ phases. In fact, Thompson et al. (1999b) state that the hydrotalcite-like precipitates not only formed early in their sorption experiments, but also persisted throughout the experiment without any changes. Similarly, the calculations indicate supersaturation of the model water with respect to the some transition metal-bearing HTLCs, suggesting that these phases are thermodynamically stable.

\section{Stability relationships between Ni HTLCs and other mineral phases}

The stability of Ni(II)-bearing HTLCs in natural waters is illustrated in Figure 1 which presents a line, calculated from thermodynamic data, indicating the equilibrium between a hypothetical solution and some selected Ni(II)bearing solids. The activity of $\mathrm{Ni}^{2+}$ (aq) and $\mathrm{H}^{+}(\mathrm{aq})$ control

Table 9. Saturation indices of HTLCs calculated from MINTEQ.

\begin{tabular}{lcccc}
\hline Case & Ni-HTLC & Co-HTLC & Mg-HTLC & Zn-HTLC \\
\hline 1 & 2.31 & -1.84 & -4.48 & 0.06 \\
2 & 2.95 & -1.34 & -3.34 & 1.28 \\
3 & 2.62 & -1.70 & -4.29 & 0.96 \\
\hline
\end{tabular}


Table 10. Free energy of formation data for mineral phases used in calculations.

\begin{tabular}{ll}
\hline Mineral phase & \multicolumn{1}{c}{$\Delta G_{\mathrm{f}}^{0}(\mathrm{~kJ} / \mathrm{mol})$} \\
\hline $\mathrm{CaCO}_{3}$ (calcite) & $-1128.5 \pm 1.4$ (Robie and Hemingway, 1995) \\
$\mathrm{Al}(\mathrm{OH})_{3}$ (gibbsite) & $-1154.9 \pm 1.2$ (Robie and Hemingway, 1995) \\
$\mathrm{Al}_{2} \mathrm{Si}_{2} \mathrm{O}_{5}(\mathrm{OH})_{4}$ & $-3797.5 \pm 1.5$ (Robie and Hemingway, 1995) \\
$\mathrm{Al}_{2} \mathrm{Si}_{4} \mathrm{O}_{10}(\mathrm{OH})_{4}$ & $-5266.2 \pm 1.5$ (Robie and Hemingway, 1995) \\
$\mathrm{Ca}^{2+}(\mathrm{aq})$ & -553.6 (Robie and Hemingway, 1995) \\
$\mathrm{NiCO}_{3}$ (gaspeite) & -612.1 (Naumov et al., 1974) \\
$\left.\beta-\mathrm{Ni}_{(\mathrm{OH}}\right)_{2}$ & -459.1 (Naumov et al., 1974) \\
$\mathrm{H}_{4} \mathrm{SiO}_{4}$ (aq) & $-1307.5 \pm 2.1$ (Robie and Hemingway, 1995) \\
\end{tabular}

the slopes of the lines and the activity of $\mathrm{CO}_{2}$ is fixed at atmospheric values. The data for these calculations are listed in Tables 2 and 10. Figure 1 presents the activity of $\mathrm{Ni}^{2+}$ (aq) as the activity of $\mathrm{H}^{2+}$ (aq) is varied as the independent variable and the following solids are considered: $\mathrm{Ni}-\mathrm{HTLC}, \beta-\mathrm{Ni}(\mathrm{OH})_{2}$ and $\mathrm{NiCO}_{3}$ (gaspeite). These reactions are illustrated in equations $4-6$

$$
\begin{gathered}
\mathrm{Ni}_{0.69} \mathrm{Al}_{0.31}(\mathrm{OH})_{2}\left(\mathrm{CO}_{3}\right)_{0.155} \cdot 0.387 \mathrm{H}_{2} \mathrm{O}(\mathrm{s})+1.38 \mathrm{H}^{+}(\mathrm{aq}) \\
0.69 \mathrm{Ni}^{2+}(\mathrm{aq})+0.31 \mathrm{Al}(\mathrm{OH})_{3}(\mathrm{~s})+ \\
0.155 \mathrm{CO}_{2}(\mathrm{~g})+1.612 \mathrm{H}_{2} \mathrm{O}(\mathrm{l}) \\
\mathrm{Ni}(\mathrm{OH})_{2}(\mathrm{~s})+2 \mathrm{H}^{+}(\mathrm{aq}) \rightarrow \mathrm{Ni}^{2+}(\mathrm{aq})+2 \mathrm{H}_{2} \mathrm{O}(\mathrm{l}) \\
\mathrm{NiCO}_{3}(\mathrm{~s})+2 \mathrm{H}^{+}(\mathrm{aq}) \rightarrow \mathrm{Ni}^{2+}(\mathrm{aq})+\mathrm{H}_{2} \mathrm{O}+\mathrm{CO}_{2}(\mathrm{~g})
\end{gathered}
$$

The lines in Figure 1 were constructed by calculating the free energies of reaction for equations 4-6. The equilibrium constants were calculated according to equation 2. As one can see, the solubility of Ni-HTLC is much less than either the solid hydroxide or the solid carbonate phase at these conditions. This result may have significance to speciation modeling in low-pH waters such as acid mine drainage in that even at $\mathrm{pH}<5$, HTLCs can form at high concentrations $\left(>10^{-4} \mathrm{M}\right)$ of $\mathrm{Ni}^{2+}$.

Figure 2 plots the stability relationships among the some soil minerals (kaolinite, pyrophyllite and calcite) and Ni-HTLC. Scaling the $\mathrm{Ni}^{2+}(\mathrm{aq})$ and $\mathrm{H}^{+}(\mathrm{aq})$ activities by their stoichiometric coefficients in equation 4 suppresses the $\mathrm{pH}$ variation in the equilibrium that is evident in Figure 1. Figure 2 plots the change in the equilibrium ratio vs. $\mathrm{H}_{4} \mathrm{SiO}_{4}^{0}(\mathrm{aq})$. The $\mathrm{Ni}$-HTLC has a considerably different stability region from that of either of the other two common soil minerals.

The data used in these calculations are listed in Tables 2 and 10. For the solid line, represented by equation 7 , the $\mathrm{Al}^{3+}$ (aq) activity is controlled by kaolinite and the $\mathrm{CO}_{3}^{2-}$ (aq) activity is controlled by calcite with the activity of $\mathrm{Ca}^{2+}$ (aq) being fixed at $10^{-6} \mathrm{M}$.

$$
\begin{gathered}
\mathrm{Ni}_{0.69} \mathrm{Al}_{0.31}(\mathrm{OH})_{2}\left(\mathrm{CO}_{3}\right)_{0.155} \cdot 0.37 \mathrm{H}_{2} \mathrm{O}(\mathrm{s})+ \\
0.31 \mathrm{H}_{4} \mathrm{SiO}_{4}(\mathrm{aq})+1.07 \mathrm{H}^{+}(\mathrm{aq})+0.155 \mathrm{Ca}^{2+}(\mathrm{aq}) \rightarrow \\
0.69 \mathrm{Ni}^{2+}(\mathrm{aq})+ \\
0.155 \mathrm{Al}_{2} \mathrm{Si}_{2} \mathrm{O}_{5}(\mathrm{OH})_{4}(\mathrm{~s})+ \\
0.155 \mathrm{CaCO}_{3}(\mathrm{~s})+2.215 \mathrm{H}_{2} \mathrm{O}(\mathrm{l})
\end{gathered}
$$

For the dashed line (equation 8 ), the $\mathrm{Al}^{3+}$ (aq) activity is controlled by pyrophyllite while $\mathrm{CO}_{3}^{2-}$ (aq) activity is controlled by calcite with the activity of $\mathrm{Ca}^{2+}$ (aq) being fixed at $10^{-6} \mathrm{M}$.

$$
\begin{gathered}
\mathrm{Ni}_{0.69} \mathrm{Al}_{0.31}(\mathrm{OH})_{2}\left(\mathrm{CO}_{3}\right)_{0.155} \cdot 0.37 \mathrm{H}_{2} \mathrm{O}(\mathrm{s})+ \\
0.62 \mathrm{H}_{4} \mathrm{SiO}_{4}(\mathrm{aq})+ \\
0.69 \mathrm{Ni}^{2+}(\mathrm{aq})+ \\
0.155 \mathrm{H}^{+}(\mathrm{aq})+0.155 \mathrm{Si}_{2} \mathrm{O}_{4} \mathrm{O}_{10}(\mathrm{OH})_{2}(\mathrm{sq})+ \\
0.155 \mathrm{CaCO}_{3}(\mathrm{~s})+2.99 \mathrm{H}_{2} \mathrm{O}(\mathrm{l})
\end{gathered}
$$

Regions above the lines represent conditions where the water is supersaturated with HTLC.

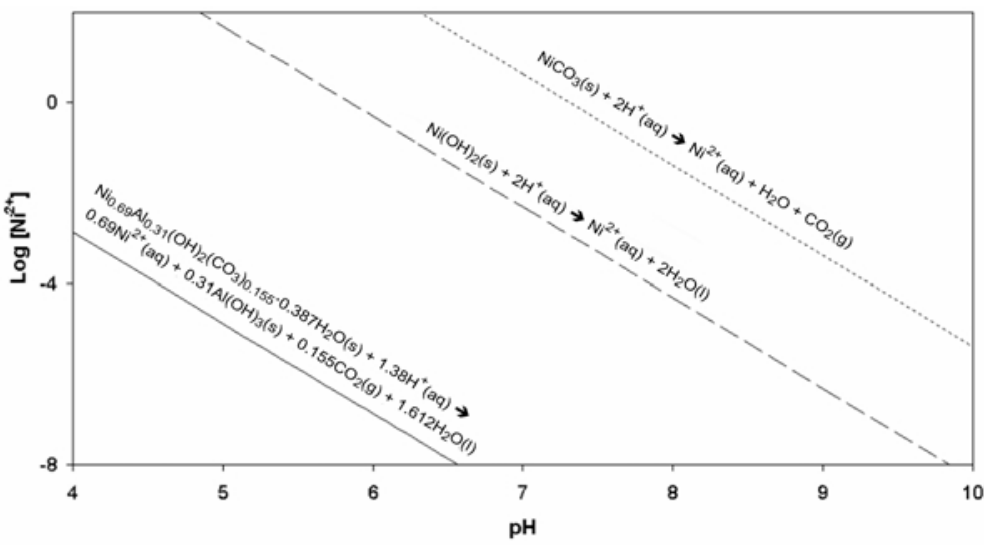

Figure 1. Stable minerals containing $\mathrm{Ni}(\mathrm{II})$ as a function of $\mathrm{pH}$. The lines represent the equilibrium between $\mathrm{Ni}^{2+}(\mathrm{aq})$, gibbsite, $\mathrm{CO}_{2}$ and Ni-HTLC (- - e equilibrium between $\mathrm{Ni}^{2+}(\mathrm{aq}), \mathrm{CO}_{2}$ and $\mathrm{NiCO}_{3}(\ldots .$.$) and equilibrium between \mathrm{Ni}^{2+}(\mathrm{aq})$ and $\mathrm{Ni}(\mathrm{OH})_{2}(---)$. The partial pressure of $\mathrm{CO}_{2}$ is fixed at $10^{-3.5}$ atm (after Drever, 1988). 


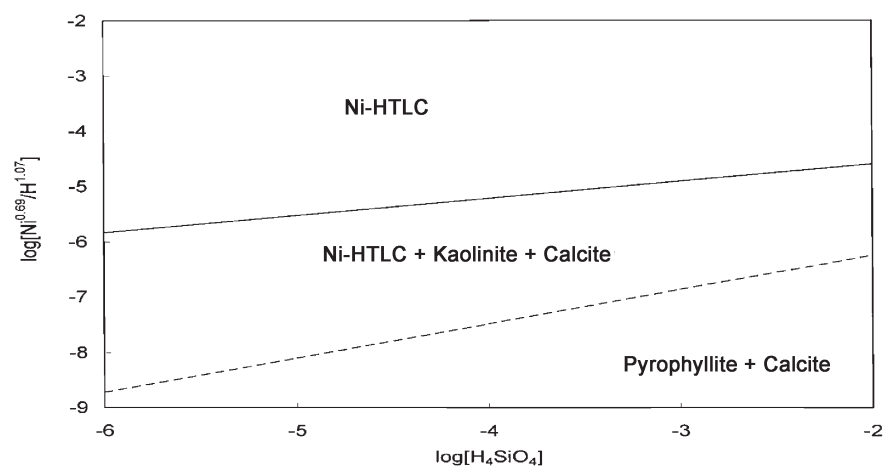

Figure 2. Stability relationships among some minerals in the $\mathrm{CaO}-\mathrm{NiO}-\mathrm{Al}_{2} \mathrm{O}_{3}-\mathrm{SiO}_{2}-\mathrm{CO}_{2}-\mathrm{H}_{2} \mathrm{O}$ as a function of the activity of key dissolved constituents at $25^{\circ} \mathrm{C}$. The solid line corresponds to equilibrium between Ni-HTLC and the minerals kaolinite and calcite calculated from equation 7 and assumptions and data listed in Tables 2 and 10. The dashed line corresponds to equilibrium between $\mathrm{Ni}-\mathrm{HTLC}$ with pyrophyllite and calcite (equation 8 ). In both cases, the activity of carbonate was fixed by equilibrium with calcite in contact with a fixed $\mathrm{Ca}^{2+}$ activity $\left(10^{-6} \mathrm{M}\right)$ (after Drever, 1988).

The important point of the figure is that HTLCs will be a significant phase in natural waters. In most natural waters the activity of $\mathrm{H}_{4} \mathrm{SiO}_{4}^{0}$ is set by equilibrium with quartz or, in volcanic terrains, X-ray amorphous solid silica. The concentrations at equilibrium vary between $10^{-4}$ and $10^{-3} \mathrm{M}$, and, because silicic-acid dissociation is negligible at $\mathrm{pH}<8$, the concentrations are relatively constant. In this concentration range, the solubility of the hydrotalcite phase varies from near $10^{-6} \mathrm{M}$ to $10^{-8} \mathrm{M}$, which is relatively insoluble. If the activity of $\mathrm{H}_{4} \mathrm{SiO}_{4}^{0}$ were smaller because of equilibrium with an aluminosilicate phase, the solubility of hydrotalcite would reduce even further (Figure 2). As indicated by the figure, however, the solubility is not very sensitive to the activity of silicic acid, given the stoichiometry of equation 8 . The important point is that the hydrotalcite phases can considerably lower the equilibrium concentration of trace metals and metal contaminants.

\section{CONCLUSIONS}

Hydrotalcite-like materials are both interesting and useful in both a geological sense and as novel materials. Here new thermochemical data for these phases are presented and their use in geochemical modeling is demonstrated. The thermodynamic data demonstrate that HTLCs are, in several cases, significantly more stable than the mechanical mixtures of hydroxides and carbonates. Measurements using high-temperature oxide melt calorimetry show varying degrees of stabilization based on the type of divalent cation. However, the exact relationship between the enthalpy of formation and the cation type is much more complex than a simple correlation between $\Delta_{\mathrm{f}} H^{\mathrm{scc}}$ and the radius of the divalent cation in the brucite-type sheet. The reduced solubility of HTLCs, as illustrated by geochemical calculations, affirms that HTLCs can form under a wide variety of conditions. Therefore including these types of phases in geochemical assessments and calculations will aid in developing more accurate predictions of the speciation and dissolved concentration of aqueous metals in the environment.

\section{ACKNOWLEDGMENTS}

This work was funded by a NEAT-IGERT fellowship and DOE grant DE FG03-97SF14749. The authors thank Sarah Roeske (UCD Geology Department) for assistance with EMPA analysis.

\section{REFERENCES}

Allada, R.K., Navrotsky, A., Berbeco, H.T. and Casey, W.H. (2002) Thermochemistry and aqueous solubilities of hydrotalcite-like solids. Science, 296, 721-723.

Allada, R.K., Boerio-Goates, J. and Navrotsky, A. (2005) Thermochemistry of hydrotalcite-like phases in the $\mathrm{MgO}$ $\mathrm{Al}_{2} \mathrm{O}_{3}-\mathrm{CO}_{2}-\mathrm{H}_{2} \mathrm{O}$ system: A determination of enthalpy, entropy and free energy. American Mineralogist, 90, $329-335$.

Allison, J.D., Brown, D.S. and Novo-Gradac, K.J. (1991) MINTEQA2/PRODEFA2: A geochemical assessment model for environmental systems. Environmental Protection Agency, Athens, GA, U.S.

Bellotto, M., Rebours, B., Clause, O., Lynch, J., Bazin, D. and Elkaim, E. (1996) A reexamination of hydrotalcite crystal chemistry. Journal of Physical Chemistry, 100, 8527-8534.

Cavani, F. and Trifirò, F. (1991) Hydrotalcite-type anionic clays: Preparation, properties and applications. Catalysis Today, 11, 173-301.

Chai, L. and Navrotsky, A. (1996) Synthesis, characterization, and enthalpy of mixing of the $(\mathrm{Fe}, \mathrm{Mg}) \mathrm{CO}_{3}$ solid solution. Geochimica et Cosmochimica Acta, 60, 4377-4383.

Drever, J.I. (1988) The Geochemistry of Natural Waters. Prentice Hall, Englewood Cliffs, New Jersey, USA.

Gustafsson, J.P. (2003) Visual MINTEQ. Department of Land and Water Resources Engineering, Royal Institute of Technology (KTH), Stockholm.

Johnson, C.A. and Glasser, F.P. (2003) Hydrotalcite-like minerals $\left(M_{2} \mathrm{Al}(\mathrm{OH})_{6}\left(\mathrm{CO}_{3}\right)_{0.5} \cdot X_{\mathrm{H}_{2}} 0\right.$, where $M=\mathrm{Mg}, \mathrm{Zn}$, $\mathrm{Co}, \mathrm{Ni}$ ) in the environment: synthesis, characterization and thermodynamic stability. Clays and Clay Minerals, 51, $1-8$.

Naumov, G.B., Ryzhenko, B.N. and Khodakovsky, I.L. (1974) Handbook of Thermodynamic Data. Washington, D.C.

Navrotsky, A. (1997) Progress and new directions in high temperature calorimetry revisited. Physics and Chemistry of Minerals, 24, 222-241.

Navrotsky, A., Rapp, R.P. Smelik, E., Burnley, P. Circone, S., 
Chai, L. and Bose, K. (1994) The behavior of $\mathrm{H}_{2} \mathrm{O}$ and $\mathrm{CO}_{2}$ in high-temperature lead borate solution calorimetry of volatile-bearing phases. American Mineralogist, 79 1099-1109.

Pausch, I., Lohse, H.H., Schurmann, K. and Allmann, R. (1986) Syntheses of disordered and Al-rich hydrotalcite-like compounds. Clays and Clay Minerals, 34, 507-510.

Reichle, W.T. (1986a) Synthesis of anionic clay-minerals (mixed metal-hydroxides, hydrotalcite). Solid State Ionics, 22, 135-141.

Reichle, W.T. (1986b) Synthesis of mixed metal-hydroxides (hydrotalcites) and their catalytic properties. Abstracts of Papers of the American Chemical Society, 191, 71.

Robie, R.A. and Hemingway, B.S. (1995) Thermodynamic Properties of Minerals and Related Substances at $298.15 \mathrm{~K}$ and 1 bar $\left(10^{5}\right.$ Pascals) and Higher Temperatures. USGS, Menlo Park, CA.

Rossini, F.D., Wagman, D.D., Evans, W.H., Levine, S. and Jaffe, I. (1952) Selected Values of Chemical Thermodynamic Properties. U.S. Department of Commerce, Washington, D.C.

Scheidegger, A.M., Lamble, G.M. and Sparks, D.L. (1997) Spectroscopic evidence for the formation of mixed-cation hydroxide phases upon metal sorption on clays and aluminum oxides. Journal of Colloid and Interface Science, 186, 118-128.

Scheidegger, A.M., Strawn, D.G., Lamble, G.M. and Sparks, D.L. (1998) The kinetics of mixed Ni-Al hydroxide formation on clay and aluminum oxide minerals: A timeresolved XAFS study. Geochimica et Cosmochimica Acta, 62, 2233-2245.

Taylor, J.R. (1982) An Introduction to Error Analysis. The
Study of Uncertainties in Physical Measurements. University Science Books, Sausalito, CA, USA.

Thevenot, F., Szymanski, R. and Chaumette, P. (1989) Preparation and characterization of Al-rich Zn-Al hydrotalcite-like compounds. Clays and Clay Minerals, 37, $396-402$.

Thompson, H.A., Parks, G.A. and Brown, G.E. (1999a) Ambient-temperature synthesis, evolution, and characterization of cobalt-aluminum hydrotalcite-like solids. Clays and Clay Minerals, 47, 425-438.

Thompson, H.A., Parks, G.A. and Brown, G.E. (1999b) Dynamic interactions of dissolution, surface adsorption, and precipitation in an aging cobalt(II)-clay-water system. Geochimica et Cosmochimica Acta, 63, 1767-1779.

Towle, S.N., Bargar, J.R., Brown, G.E. and Parks G.A. (1997) Surface precipitation of $\mathrm{Co}(\mathrm{II})(\mathrm{aq})$ on $\mathrm{Al}_{2} \mathrm{O}_{3}$. Journal of Colloid and Interface Science, 187, 62-82.

Wagman, D.D., Evans, W.H., Parker, V.B., Halow, I., Bailey, S.M., Schumm, R.H., Churney, K.L. and Nuttal, R.L. (1982) The NBS tables of chemical thermodynamic properties: Selected values for inorganic and $\mathrm{C}_{1}$ and $\mathrm{C}_{2}$ organic substances in SI units. Journal of Physical and Chemical Reference Data 11(Supplement No. 2), 392 pp.

Wang, M.J. and Navrotsky, A. (2004) Enthalpy of formation of $\mathrm{LiNiO}_{2}, \mathrm{LiCoO}_{2}$ and their solid solutions $\mathrm{LiNi}_{1-\mathrm{x}} \mathrm{CO}_{\mathrm{x}} \mathrm{O}_{2}$. Solid State Ionics, 166, 167-173.

Woods, T.M. and Garrels, R.M. (1987) Thermodynamic Values at Low Temperature for Natural Inorganic Materials: An Uncritical Summary. Oxford University Press, New York.

(Received 6 December 2004; revised 17 February 2006; Ms. 988; A.E. David A. Laird) 